Quaternary Science Reviews. Volume 233, 1 November 2019, 105851

\title{
Human occupation of Northern Europe in MIS 13: a response to comments by Gibbard et al. (2019)
}

\author{
Simon G. Lewis ${ }^{\mathrm{a}}$, Nick Ashton ${ }^{\mathrm{b}}$, Peter G. Hoare ${ }^{\mathrm{ab}}$, Simon Parfitt $^{\mathrm{cd}}$ \\ ${ }^{a}$ School of Geography, Queen Mary University of London, Mile End Road, London, E1 4NS, \\ UK. \\ ${ }^{\mathrm{b}}$ Department of Britain, Europe \& Prehistory, British Museum, Franks House, 38-56 Orsman \\ Road, London, N1 5QJ, UK. \\ ${ }^{\mathrm{c}}$ Institute of Archaeology, University College London, 31-34 Gordon Square, London, \\ WC1H 0PY, UK. \\ ${ }^{\mathrm{d}}$ Department of Earth Sciences, Natural History Museum, Cromwell Road, London, SW7 \\ $5 \mathrm{BD}, \mathrm{UK}$
}

Received 29 June 2019, Accepted 8 July 2019, Available online 6 September 2019.

\begin{abstract}
In a recent paper (Lewis et al., 2019) we reported the results of geological and archaeological investigations at Happisburgh Site 1. We also considered the significance of the site for understanding the human occupation of northern Europe during the early Middle Pleistocene. In a comment on the paper, Gibbard et al. (2019) raise a number of issues concerning lithostratigraphic terminology, the age of the deposits at Site 1, and the wider regional context of the Site 1 archaeological assemblage. Here we respond to Gibbard and colleagues' objections and, in particular, we present evidence in support of our contention that the Palaeolithic assemblages from the Breckland sites of Warren Hill and High Lodge pre-date the Anglian (MIS 12) glaciation and may be considered to date to MIS 13.
\end{abstract}

\section{Introduction}

Comments by Gibbard et al. (2019) on our paper on Happisburgh Site 1 (Lewis et al., 2019) cover three main issues: the nomenclature that is used to refer to the glacial and Cromer Forest-bed Formation (CF-bF) sediments on the coast of Norfolk; the age of the deposits underlying the glacial succession at Happisburgh Site 1; and the correlation of the artefact assemblage from Happisburgh Site 1 with those from other sites, particularly Warren Hill and High Lodge in the Breckland of Suffolk. Contrary to the contention of Gibbard et al., we do not correlate these sites by means of their archaeological assemblages. We welcome this opportunity to respond to the issues that have been raised. 


\section{Nomenclature of Quaternary sediments in Norfolk}

The statement that we display "a lack of understanding of the regional geological setting of the site at Happisburgh and of lithostratigraphical terminology" is unfounded. Gibbard et al. suggest that the 'correct' formal lithostratigraphic term for the glacial sequence at Happisburgh is the 'North Sea Drift Formation'. This term was used in the reclassification of the Quaternary deposits of the British Isles (Bowen, 1999). Since then, as a result of remapping by the British Geological Survey (BGS), a different stratigraphic terminology has evolved in which, as discussed by Lee et al. (2004a), the problematic term 'North Sea Drift' was discontinued and new formation names were proposed and are now employed by the BGS (e.g. Moorlock et al., 2002; Lee et al., 2004a, 2015, 2017). A detailed consideration of the glacial stratigraphy was beyond the scope of our paper and we adopted this scheme as it provides an appropriate framework and nomenclature.

Gibbard et al. also express concern about our omission of the term 'Hill House Member'. This is a result of their misunderstanding of the stratigraphy and nomenclature of the deposits at Happisburgh sites 1 and 3. In our original definition of the term 'Hill House Formation' (Parfitt et al., 2010), subsequently renamed the Hill House Member (Gibbard, 2012), these sediments were recognised as a mappable series of organic-rich laminated silts which underlie the glacial succession and overlie sands of the Crag Group. They extend from the northern end of Site 3 to West's (1980) borehole location HC on the now-destroyed slipway. These sediments are located c. $1 \mathrm{~km}$ to the north-west of Site 1, and the Hill House Member at Site 3 has no demonstrable connection with the Site 1 sediments (Ashton et al., 2014). The organic mud at Happisburgh Site 1 is the infill of an abandoned channel and we defined a new lithostratigraphic unit, the 'Low Lighthouse Member', a constituent of the CF-bF (see our table 4), to refer to this unit. It is unsurprising that we made no mention of the Hill House Member as it has no bearing on the subject of the paper.

\section{Age of the Happisburgh Site 1 sediments}

A further issue that Gibbard et al. raise is the age of the Happisburgh Site 1 succession. We argue that the glacial sediments are of Anglian (MIS 12) age, with which Gibbard et al. concur, although we do cite alternative views (e.g. Lee et al., 2004b). We also note that Gibbard et al. agree with our view that the normal polarity of the Low Lighthouse Member indicates an age within the Brunhes Chron, i.e. $<780 \mathrm{kyr}$. There is therefore no disagreement on these upper and lower age constraints.

Gibbard et al. take issue with our refinement of the age of the Low Lighthouse Member (p.45). Our principal argument is based on the presence of unrooted molars of the water vole Arvicola, a species that appears in the latter part of the 'Cromerian Complex' (Preece and Parfitt, 2012). Critically,Arvicola is present at Sidestrand and Waverley Wood, where amino acid geochronology suggests attribution to MIS 13, though it is probable that these sites represent different parts of a complex interglacial stage (Preece et al., 2009; Penkman et al., 2011; Preece and Parfitt, 2012). We argue that an MIS 13 age assignment for the Low Lighthouse Member is consistent with the information that is currently available. We reiterate our conclusion that " $[\mathrm{t}]$ he combination of litho-, magneto- and biostratigraphic evidence from 
Happisburgh Site 1 suggests that the Low Lighthouse Member dates to the latter part of the 'Cromerian Complex' and is probably attributable to MIS 13” (p.45 [emphasis added]).

\section{Correlation with other sites attributed to MIS 13}

Gibbard et al. devote the second part of their comment to rehearsing their interpretation of sediments in western Norfolk and Suffolk that have been attributed to the erstwhile Bytham River (Gibbard et al., 2009, 2012a, b, 2018; West et al., 2014). They have argued that a number of sites along the eastern margin of the Fens, including Maidscross Hill and Warren Hill, record evidence for post-Anglian glaciation of the Fens in an ice-marginal setting along the so-called 'Skertchly Line'. They attribute this glaciation to the late Saalian (MIS 6). They further suggest that the High Lodge clayey silts were deposited on top of, and therefore postdate, Anglian till in a doline formed by solution of the underlying Chalk bedrock, and that subsequently these sediments were disrupted by this same late Saalian glaciation.

In our view, there are major problems with this interpretation. Discussion of these issues was not central to the purpose of the Happisburgh Site 1 paper and therefore was not considered in that context. However, an outline of the main arguments is presented here.

\subsection{Clast lithology of the gravels}

The proposal of a former Bytham River, which flowed from the Midlands across what is now the Fen Basin, into East Anglia and thence to the North Sea, is based primarily on a series of sites where gravels with a consistent and significant quartz, quartzite and Carboniferous chert component, derived from the English Midlands, have been identified (Rose, 1987,1989, 1994, 2009; Lewis, 1993; Lewis et al., 1999; Lee et al., 2004b, 2015).

In the first publication of their alternative interpretation, Gibbard et al. (2009, their table 2) present clast lithological data from seven sites that lie on the Skertchly Line. Their data reveal that the five samples from Warren Hill and Maidscross Hill have quartz+quartzite percentages of between 34\% and 49\%. The other nine samples from Barton Mills, Hockwold, Windmill Farm, Exning Hospital and Portway Hill have percentages between 0 and 10\%, other than Windmill Farm Unit 6 with 19.8\%. These data show that the gravels can be divided into two groups based on their clast lithology and that Warren Hill and Maidscross Hill have a considerably higher proportion of quartzite and quartz than the other sites. There is therefore good evidence to sustain the attribution of Warren Hill and Maidscross Hill to the pre-Anglian Bytham River.

\subsection{Numerical dating}

Gibbard et al. refer to "published and unpublished numerical optical spin resonance (sic) dating" in support of a later Middle Pleistocene age. Presumably these are the Optically Stimulated Luminescence (OSL) dates previously cited by Gibbard et al. (2009) of $c .160 \mathrm{kyr}$ on the sands at Warren Hill and on the Tottenhill sands and gravels. The details of these age estimates remain unpublished. More recently, Electron Spin Resonance (ESR) dating has been applied to samples from Warren Hill, from the same unit as the unpublished OSL date 
(two samples; $544 \pm 53 \mathrm{kyr}, 539 \pm 38 \mathrm{kyr}$ ) and also from Maidscross Hill (two samples; $529 \pm 55 \mathrm{kyr}, 631 \pm 56 \mathrm{kyr}$ ) and these indicate an age that is consistent with deposition prior to the Anglian glaciation (Voinchet et al., 2015). These age estimates were produced as part of a wider ESR dating programme in Britain and France, which also included other Breckland sites. Of significance in this context are Barnham and Beeches Pit, which clearly post-date the Anglian glaciation. Here the ESR age estimates are consistent with a previous attribution of these sites to MIS 11 (Ashton et al., 1998; Preece et al., 2007). Further ESR dating, undertaken as part of the Breckland Palaeolithic Project, will add to the chronological constraints on both pre-Anglian and post-Anglian deposits in the Breckland (Davis et al., 2017).

\subsection{High Lodge}

High Lodge is a complex site that lies $1 \mathrm{~km}$ north of Warren Hill. We reject the statement that, with regard to High Lodge, we have "overlooked the fact that the [clayey] silts ... overlie, rather than underlie, Anglian-age Lowestoft Formation glacial diamicton". Our interpretation of this succession is set out in full in Ashton et al. (1992). There it was argued that the High Lodge clayey silts (Beds B and C) were floodplain sediments of the Bytham River and were subsequently glaciotectonised by Anglian ice, as a result of which they overlie, but pre-date, the glacial diamicton that was deposited by that ice sheet. The reinterpretation put forward by West et al. (2014) involving a doline formed after the Anglian glaciation in which the clayey silts were deposited then subsequently glaciotectonised by a late Saalian glaciation of the Fenland region, has four main flaws when compared with our interpretation.

Characteristics of the High Lodge clayey silts. One of the critical lines of evidence for attributing the High Lodge clayey silts to the Bytham River is the material contained within those sediments: a quartz- and quartzite-rich clast lithology (Lewis, 1992); a heavy mineral suite also derived from Triassic bedrock sources in the Midlands (Rose et al., 1992); and a pre-Quaternary palynomorph assemblage derived from bedrock sources west of the Fen Basin (Hunt and Rose, 1992). Importantly, the clast lithological and mineralogical content of the clayey silts distinguishes them from the glacial deposits and suggests that the former have not been derived from the latter. This is contrary to what would be expected from sediments that accumulated within a doline formed after the deposition of the Anglian glacial sediments and, furthermore, would inevitably have been derived from the glacial deposits in the vicinity of the doline as envisaged by West et al. (2014). This evidence supports an interpretation of the High Lodge clayey silts as floodplain sediments deposited within the Bytham River system.

Evidence for a doline. The configuration of the surface of the Chalk at High Lodge is known from only four boreholes (Lewis, 1992) but gives little indication of a doline-like basin. However, in the doline model set out by West et al. (2014, Fig. 16), and assuming it to be a solution doline that developed by bedrock solutional subsidence, percolating groundwater would dissolve the calcareous component of the glacial sediments which overlie the Chalk and pre-date doline formation, leaving a decalcified residual deposit of mainly flint clasts in a stony clay matrix. No such deposit has been identified and there is no evidence of significant 
solution; calcareous glacial sediments were observed in several sections and noted in 21 boreholes beneath the High Lodge clayey silts across the area. The evidence does not, in our view, support the presence of a doline.

Glaciotectonised High Lodge clayey silts. Gibbard et al. agree with our interpretation that the clayey silts were glacially tectonised (West et al., 2014), but they argue that this was by late Saalian rather than by Anglian ice. In our interpretation, the lower diamicton, which is part of the Lowestoft Formation, and the High Lodge clayey silts are interdigitated as a result of glaciotectonic deformation processes arising from shear stresses imparted by the Anglian ice (Lewis, 1992). In contrast, there is no till at High Lodge that can be attributed to the late Saalian (the upper diamicton being a debris flow deposit reworked from the lower diamicton), so Gibbard et al.'s alternative interpretation invokes a glacial event, but without the glacial sediments deposited by the ice that was responsible for that process. We take a simpler approach and argue that the ice responsible for that process is evident from the Lowestoft Till.

Biostratigraphy. A significant piece of evidence that Gibbard et al. dismiss is a rhinoceros tooth fragment from the clayey silts. This was originally attributed to Dicerorhinus etruscus (Stuart, 1992) but was reassigned to Stephanorhinus hundsheimensis (Breda et al., 2010). This is an early Middle Pleistocene species and suggests a pre-Anglian age for the clayey silts. West et al. (2014) argue that the rhinoceros tooth is reworked, along with nonlocal clasts and palynomorphs. However, the tooth is in remarkably fresh condition with no indication of having been reworked.

In our view the evidence from High Lodge, including the biostratigraphically important rhinoceros tooth and the distinctive lithological and mineralogical character of the High Lodge clayey silts, is consistent with their interpretation as Bytham River floodplain sediments. The archaeological assemblage contained within the High Lodge clayey silts therefore pre-dates the Anglian glaciation.

\section{Concluding comments}

We are happy to engage in a discussion of Happisburgh and its wider context and significance. There is strong evidence, based on stratigraphy, clast lithology, numerical dating and biostratigraphy, to support the identification of the Bytham River on the eastern Fenland margin and for Warren Hill, Maidscross Hill, High Lodge and other Breckland sites (e.g. Brandon Fields, Rampart Field) to be considered as part of that river system. Gibbard et al. are incorrect in stating that we base this interpretation on archaeology. Our approach has been the opposite of this, by using the non-archaeological evidence to make a comparison between these sites and then to identify technological similarities among the archaeological assemblages. It should also be emphasised that the British sites constitute a highly significant dataset for understanding the human occupation of Europe in the early Middle Pleistocene. We recognise that Gibbard et al. have come to a different understanding of the Fenland margin sites, but we contend that their interpretation does not adequately account for all the available evidence and that the Bytham River remains a viable, rather than "failed", concept within which these important sites can be interpreted. 
Finally, returning to Happisburgh, nomenclatural differences aside, there is no substantive disagreement between us and Gibbard et al. concerning the glacial deposits, nor do they question the depositional model and environmental context that we have proposed for the archaeological assemblages from Site 1. The work at Happisburgh over the last two decades has shown that new discoveries can challenge long-held notions concerning the Quaternary and the Palaeolithic, and future research may yet swing the balance of the debate in one direction or another.

\section{Acknowlegdement}

Research at Happisburgh has been supported by the British Museum, the Natural Environment Research Council (NE/C508918/1), the British Academy (SG37889), the Ancient Human Occupation of Britain project funded by the Leverhulme Trust, the Pathways to Ancient Britain project funded by the Calleva Foundation, the University of Leiden, the Netherlands Organization for Scientific Research (NWO Spinoza grant) and Historic England (projects 6234 and 6441).

\section{References}

N.M. Ashton, J. Cook, S.G. Lewis, J.Rose (Eds.), 1992. High Lodge. Excavations by G. de G. Sieveking, 1962-68 and J. Cook, 1988, British Museum Press, London.

N.M. Ashton, S.G. Lewis, I. DeGroote, S.M.

Duffy, M. Bates, R. Bates, P.G. Hoare, M. Lewis, S.A. Parfitt, S. Peglar, C. Williams, 2014. Hominin footprints from early Pleistocene deposits at Happisburgh, UK. PLoS

One, 9 (2) (2014), Article e88329.

N.M. Ashton, S.G. Lewis, S.A. Parfitt (Eds.), 1998. Excavations at the Lower Palaeolithic Site at East Farm, Barnham, Suffolk 1998-94. British Museum Occasional Paper 125, British Museum Press, London.

D.Q. Bowen (Ed.), 1999. A Revised Correlation of Quaternary Deposits in the British Isles, Geological Society London. Special Report No. 23.

M. Breda, S.E. Collinge, S.A. Parfitt, A.M.Lister, 2010. Metric analysis of ungulate mammals in the early Middle Pleistocene of Britain, in relation to taxonomy and biostratigraphy: I: Rhinocerotidae and Bovidae. Quat. Int., 228, pp. 136-156.

R.J. Davis, S.G. Lewis, N.M. Ashton, S.A. Parfitt, M.T. Hatch, P.G. Hoare, 2017. The early Palaeolithic archaeology of the Breckland: current understanding and directions for future research. J. Breckland Stud., 1, pp. 28-44.

P. Gibbard, 2012. The status of the Hill House 'Formation' at Happisburgh, Norfolk, England. Quat. Int., 271, pp. 29-30.

P.L. Gibbard, A.H. Pasanen, R.G. West,J.P. Lunkka, S. Boreham, K.M. Cohen, C.J. Rolfe, 2009. Late Middle Pleistocene glaciation in East Anglia, England. Boreas, 38, pp. 504-528 
P.L. Gibbard, R.G. West, S. Boreham,C.J. Rolfe, 2012. Late Middle Pleistocene ice-marginal sedimentation in East Anglia, England. Boreas, 41, pp. 319-336.

P.L. Gibbard, R.G. West, S. Boreham,C.J. Rolfe, 2012. Late Middle Pleistocene glaciofluvial sedimentation in Norfolk, England. Neth. J. Geosci., 91, pp. 63-78.

P.L. Gibbard, R.G. West, P.D. Hughes, 2018. Pleistocene glaciation of Fenland, England, and its implications for evolution of the region. R. Soc. Open Sci., 5, 52pp.

P.L. Gibbard, P.D. Hughes, R.G. West, 2019. Human occupation of northern Europe in MIS 13: Happisburgh Site 1 (Norfolk, UK) and its European context: A response to Lewis et al. Quat. Sci. Rev., 223.

C.O. Hunt, J. Rose, 1992. Recycled palynomorphs from the High Lodge clayey-silts. N.M. Ashton, J. Cook, S.G. Lewis, J. Rose (Eds.), High Lodge. Excavations by G. de G. Sieveking, 1962-68 and J. Cook, 1988, British Museum Press, London, pp. 103-115.

J.R. Lee, S.J. Booth, R.J.O. Hamblin, A.M.Jarrow, H. Kessler, B.S.P. Moorlock, A.N. Morigi , A.Palmer, J.B. Riding, J. Rose, 2004. A new stratigraphy for the glacial deposits around Lowestoft, Great Yarmouth, North Walsham and Cromer, East Anglia, UK. Bull. Geol. Soc. Norfolk, 53, pp. 3-60.

J.R. Lee, E. Phillips, J. Rose, D. Vaughan-Hirsch, 2017. The Middle Pleistocene glacial evolution of northern East Anglia, UK: a dynamic tectonostratigraphic-parasequence approach. J. Quat. Sci., 32, pp. 231-260.

J.R. Lee, J. Rose, R.J.O. Hamblin, B.S.P. Moorlock, 2004. Dating the earliest lowland glaciation of eastern England: the pre-Anglian early Middle Pleistocene Happisburgh Glaciation. Quat. Sci. Rev., 23, pp. 1551-1566.

J.R. Lee, M.A. Woods, B.S.P. Moorlock (Eds.), 2015. British Regional Geology: East Anglia (fifth ed.), British Geological Survey, Keyworth, Nottingham.

S.G. Lewis, 1992. High Lodge-stratigraphy and depositional environments.

N.M. Ashton, J. Cook, S.G. Lewis, J. Rose (Eds.), High Lodge. Excavations by G. de G. Sieveking, 1962-68 and J. Cook, 1988, British Museum Press, London, pp. 51-85.

S.G. Lewis, 1993. The Status of the Wolstonian Glaciation in the English Midlands and East Anglia. Unpublished PhD Thesis University of London.

S.G. Lewis, J. Rose, H. Davies, 1999. Pre-Anglian fluvial and Anglian glaciogenic sediments Knettishall, Suffolk, England. Proc. Geologists' Assoc., 110, pp. 17-32.

S.G. Lewis, N. Ashton, M.H. Field, P.G.Hoare, H. Kamermans, M. Knul, H.J. Mücher, S.A.P arfitt, W. Roebroeks, M.J. Sier, 2019. Human occupation of northern Europe in MIS 13:

Happisburgh site 1 (Norfolk, UK) and its European context. Quat. Sci. Rev., 211, pp. 34-58.

B.S.P. Moorlock, R.J.O. Hamblin, S.J. Booth, M.A. Woods, 2002. Geology of the Mundesley and North Walsham District - a Brief Explanation of the Geological Map. Sheet 
Explanation of the British Geological Survey, 1:50 000 Series Sheets 132 and 148 Mundesley and North Walsham (England and Wales). British Geological Survey, Keyworth.

S.A. Parfitt, N.M. Ashton, S.G. Lewis,R.L. Abel, G.R. Coope, M.H. Field, R. Gale, P.G.Hoar e, N.R. Larkin, M.D. Lewis, V. Karloukovski, B.A.Maher, S.M. Peglar, R.C. Preece, J.E. Wh ittaker, C.B.Stringer, 2010. Early Pleistocene human occupation at the edge of the boreal zone in northwest Europe. Nature, 466, pp. 229-233.

K.E.H. Penkman, R.C. Preece, D.H.Keen, T. Meijer, T.S. White, M.J. Collins, 2011. A chronological framework for the British Quaternary based on calcitic Bithynia opercula. Nature, 476, pp. 446-449.

R.C. Preece, S.A. Parfitt, 2012. The Early and early Middle Pleistocene context of human occupation and lowland glaciation in Britain and northern Europe. Quat. Int., 271, pp. 16-28.

R.C. Preece, S.A. Parfitt, D.R. Bridgland,S.G. Lewis, P.J. Rowe, T.C. Atkinson, I. Candy, N. C. Debenham, K.E.H. Penkman, E.J. Rhodes, J.L. Schwenninger, 2007. Terrestrial environments during MIS 11: evidence from the Palaeolithic site at West Stow, Suffolk, UK. Quat. Sci. Rev., 26 (9-10), pp. 1236-1300.

R.C. Preece, S.A. Parfitt, G.R. Coope, K.E. Penkman, P. Ponel, J.E. Whittaker, 2009. Biostratigraphic and aminostratigraphic constraints on the age of the Middle Pleistocene glacial succession in north Norfolk, UK. J. Quat. Sci., 24, pp. 557-580.

J. Rose, 1987. The status of the Wolstonian glaciation in the British Quaternary. Quat. Newsl., 53, pp. 1-9.

J. Rose, 1989. Tracing the Baginton-Lillington sands and gravels from the West Midlands to East Anglia. D.H. Keen (Ed.), The Pleistocene of the West Midlands: Field Guide, Quaternary Research Association, Cambridge, pp. 102-110.

J. Rose, 1994. Major river systems of central and southern Britain during the early and Middle Pleistocene. Terra Nova, 6, pp. 435-443.

J. Rose, 2009. Early and Middle Pleistocene landscapes of eastern England. Proc. Geologists' Assoc., 120, pp. 3-33.

J. Rose, H. Davies, S.G. Lewis, 1992. Heavy mineral composition of the sands at High Lodge. N.M. Ashton, J. Cook, S.G. Lewis, J. Rose (Eds.), High Lodge. Excavations by G. de G. Sieveking, 1962-68 and J. Cook, 1988, British Museum Press, London, pp. 94-102.

A.J. Stuart, 1992. The High Lodge mammalian fauna.

N.M. Ashton, J. Cook, S.G. Lewis, J. Rose (Eds.), High Lodge. Excavations by G. de G. Sieveking, 1962-68 and J. Cook, 1988, British Museum Press, London, pp. 121-123.

P. Voinchet, D. Moreno, J.J. Bahain, H.Tissoux, O. Tombret, C. Falguères, M.H. Moncel, D. Schreve, I. Candy, P. Antoine, N. Ashton, M. Beamish,D. Cliquet, J. Despriée, S.G. Lewis, N . Limondin-Lozouet, J.-L. Locht, S. Parfitt, M. Pope, 2015. New chronological data (ESR and ESR/U-series) for the earliest Acheulian sites of north-western Europe. J. Quat. Sci., 30, pp. 610-622. 
R.G. West, 1980. The Pre-glacial Pleistocene of the Norfolk and Suffolk Coasts. Cambridge University Press, Cambridge.

R.G. West, P.L. Gibbard, S. Boreham, C.J. Rolfe, 2014. Geology and geomorphology of the Palaeolithic site at High Lodge, Mildenhall, Suffolk, England. Proc. Yorks. Geol. Soc., 60, pp. 99-121. 